\title{
Aerobic Exercise Alleviates Inflammation, Oxidative Stress, and Apoptosis in Mice with Chronic Obstructive Pulmonary Disease [Corrigendum]
}

Wang X, Wang Z, Tang D. Int J Chron Obstruct Pulmon Dis. 2021;16:1369-1379.

The authors have advised due to an error at the time of figure assembly, Figures 3 and 7 on pages 1375 and 1378, respectively are incorrect. The correct Figures 3 and 7 are as follows.

The authors apologize for this error and advise it does not affect the results of the paper.
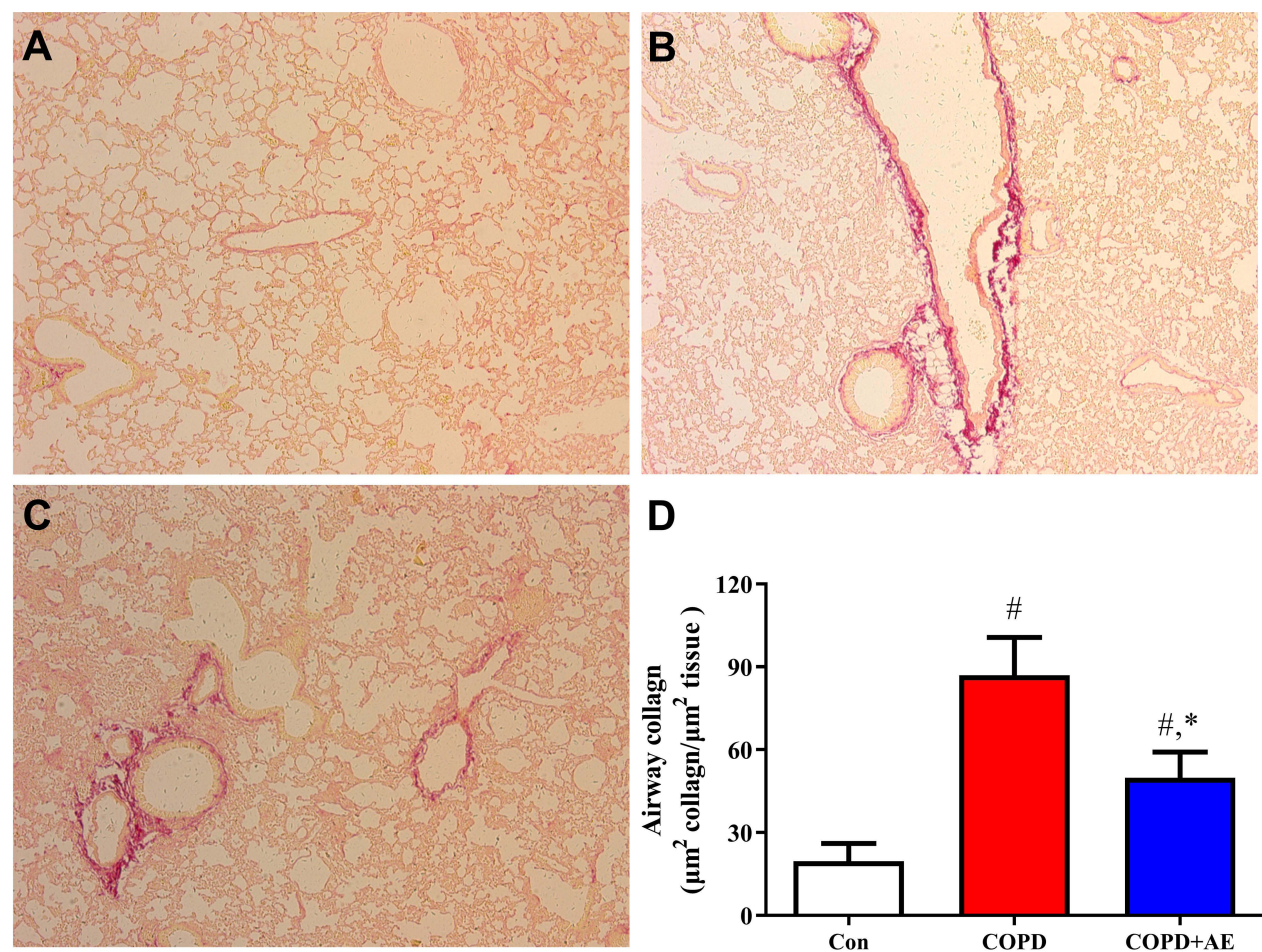

D

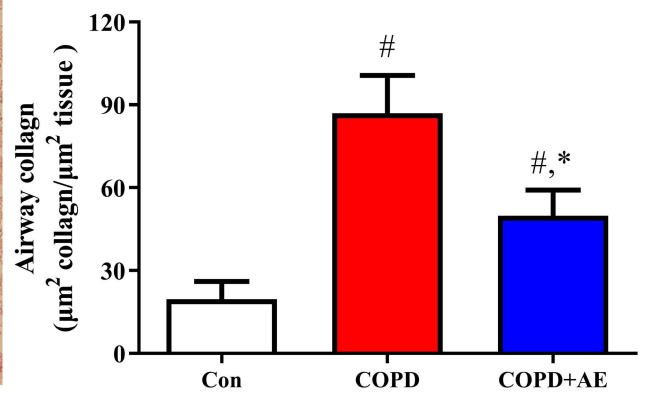

Figure 3 Detection of airway fibrosis.

Notes: (A) Con group. (B) COPD group. (C) COPD+AE group. (D) Detection of collagen fiber deposition in the airway wall. The airway collagen increased after LPS administration, while exercise administration decreased fibrotic score. The results were expressed as $\mu \mathrm{m} 2$ of collagen fibers per $\mu \mathrm{m} 2$ of tissue area. ${ }^{\#} P<0.05$ compared with the Con group. $* P<0.05$ compared with the COPD group (magnification, $x 40$ ). 

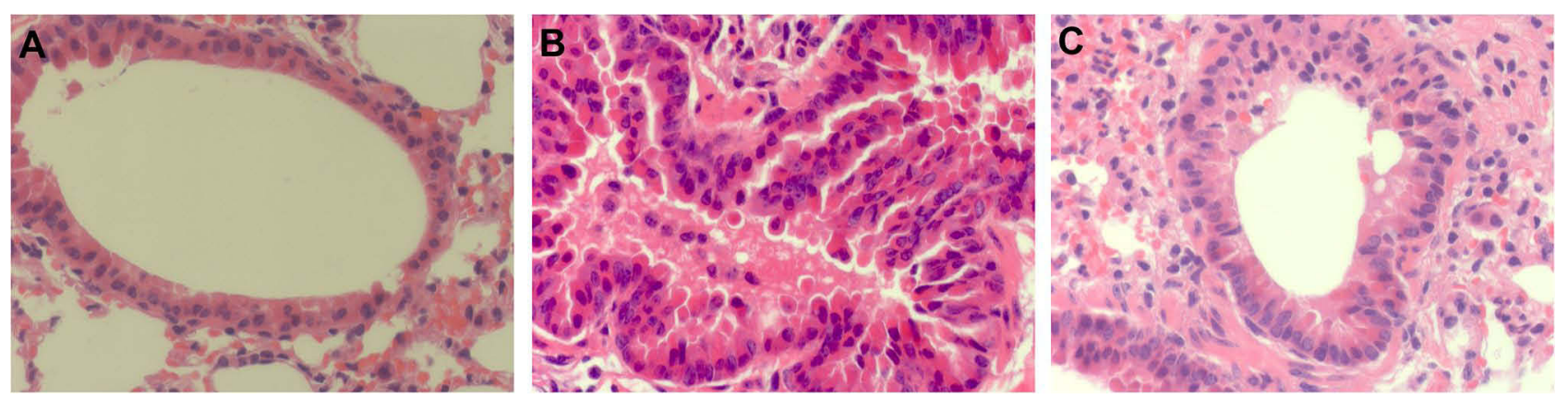

Figure 7 Detection of bronchial mucus cell hyperplasia and bronchoconstriction.

Notes: (A) Con group. (B) COPD group. (C) COPD+AE group. LPS administration led to severe bronchial mucus cell hyperplasia and bronchoconstriction, while 4 weeks of $A E$ improved bronchial mucus cell hyperplasia and bronchoconstriction (magnification, $\times 400$ ).

\section{Publish your work in this journal}

The International Journal of COPD is an international, peer-reviewed journal of therapeutics and pharmacology focusing on concise rapid reporting of clinical studies and reviews in COPD. Special focus is given to the pathophysiological processes underlying the disease, intervention programs, patient focused education, and self management protocols. This journal is indexed on PubMed Central, MedLine and CAS. The manuscript management system is completely online and includes a very quick and fair peer-review system, which is all easy to use. Visit http://www.dovepress.com/testimonials.php to read real quotes from published authors. 